\title{
PENERAPAN MODEL PROJECT-BASED LEARNING DALAM MATA DIKLAT GAMBAR SKETSA
}

\author{
Ambiyar, Budi Syahri, Junil Adri, Primawati, Nurhaliza, dan Syaiful Islami \\ Fakultas Teknik Universitas Negeri Padang \\ email: ambiyar@ft.unp.ac.id
}

\begin{abstract}
Abstrak
Tujuan dari penelitian ini untuk meningkatkan motivasi belajar, keterampilan, dan hasil belajar Mata Diklat Gambar Sketsa siswa kelas X Sekolah Menengah Kejuruan (SMK) Semen Padang dengan menerapkan model Project-based learning (PjBL). Penelitian menggunakan Penelitian Tindakan Kelas (PTK). Ada dua siklus yang dilakukan dalam penelitian ini. Masing-masing siklus terdiri dari dua kali pertemuan sehingga ada empat pertemuan untuk dua siklus. Subjek penelitian adalah siswa kelas X Teknik Mesin 1 di SMK Semen Padang dengan jumlah 20 siswa. Instrumen penelitian yang digunakan adalah lembar observasi, tes objektif, dan rubrik. Lembar observasi digunakan untuk mengamati motivasi belajar, rubrik digunakan untuk menilai keterampilan, dan tes obyektif digunakan untuk menilai hasil belajar siswa. Data dianalisis dengan menggunakan statistik deskriptif. Temuan penelitian menunjukkan adanya peningkatan motivasi belajar dan keterampilan siswa dari siklus 1 ke siklus 2 dalam Mata Diklat Gambar Sketsa dengan menerapkan model PjBL. Hasil belajar siswa juga sudah mencapai Kriteria Ketuntasan Minimal (KKM).
\end{abstract}

Kata kunci: project-based learning, motivasi, keterampilan, hasil belajar, gambar sketsa

\section{APPLICATION OF PROJECT-BASED LEARNING MODEL IN SKETCH DRAWING SUBJECT}

\begin{abstract}
This study was aimed at improving learning motivation, skills, and learning outcomes in the Sketch Drawing training course for students of tenth grade, Semen Padang Vocational High School by applying Project-based learning (PjBL) model. The study used Classroom Action Research (CAR). There were two cycles carried out in this study. Each cycle consists of two meetings, so there are four meetings for two cycles. The research subjects were 20 students of Class X Mechanical Engineering 1 at Semen Padang Vocational School. The research instruments used were observation sheets, objective tests, and rubrics. The observation sheets were used to observe motivation to learn, rubrics were used to assess skills, and objective tests were used to assess student learning outcomes. The data obtained then were analyzed using descriptive statistics. The results show that there is an improvement in learning motivation and student skills from cycle 1 to cycle 2 in the Sketch Drawings by appying PBL model. Student learning outcomes have also reached the Minimum Criteria of Mastery Learning (MCML).

Keywords: project-based learning, motivation, skills, learning outcome, sketch drawing
\end{abstract}




\section{PENDAHULUAN}

Peningkatan mutu pendidikan selalu ditingkatkan agar siswa dapat memiliki kemampuan yang baik untuk barsaing di dunia kerja. Upaya pengembangunan model pembelajaran selalu di kembangkan untuk memberikan peluang bagi guru dalam memberikan pembelajaran yang efektif. Salah satu pengembangan model pembelajaran yang dapat diterapkan pada proses pembelajaran adalah model Projectbased Learning.

Model Project-based Learning $(P j B L)$ merupakan model pembelajaran berbasis proyek. Wena (2014, p. 144) menyatakan model PjBL merupakan model pembelajaran yang memberikan kesempatan kepada guru untuk mengelola kelasnya dengan melibatkan kerja proyek. Pengembangan model pembelajaran berbasis proyek ini dapat melatih siswa untuk dapat meningkatkan kerampilan belajar.

Jurusan Teknik Mesin memberikan peluang kepada siswa untuk mengembangkan keterampilan melalui beberapa program pembelajaran misalnya, keterampilan pengelasan, menggunakan mesin produksi, menganalisis bahan kerja, perancangan, dan kontruksi benda. Sekolah Menengah Kejuruan (SMK) Semen Padang merupakan sekolah menengah kejuruan swasta di Kota Padang yang berlokasi di kompleks PT Semen Padang jalan raya Padang-Indarung. SMK Semen Padang memiliki mata diklat program produktif yang memberikan pembekalan kepada siswa tentang penguasaan kompetensi yang meliputi aspek pengetahuan, keterampilan, dan sosial. Salah satu program produktif yang terdapat pada Jurusan Teknik Mesin adalah Mata Diklat Gambar Sketsa. Mata Diklat Gambar Sketsa dikembangkan pada kelas X. Materi yang dikembangkan pada pembelajaran Gambar Sketsa di antaranya,
Gambar Piktorial, Gambar Orthogonal, Ukuran, dan Potongan.

Gambar proyeksi piktorial merupakan gambar dari suatu benda kerja yang dilukis menurut garis-garis pandangan pengamat pada suatu bidang datar/bidang gambar. Madsen dan Madsen (2012, p. 563) menyatakan pictorial drawings are useful in mechanical design, manufacturing production, architecture, construction, assembly instructions, service and repair manuals, and sales brochures. Giesecke et al. (2016, p. 80) mengatakan pictorial drawings are often used to show how parts fit together in an assembly and, in part catalogs and manuals, to make it easy to identify the objects.

Proyeksi piktorial terdiri dari proyeksi isometris, dimetris, oblik, dan perspektif. Rathnam (2018, p. 321) menyatakan bahwa isometric projection is an orthographic projection of an object on the vertical plane showing its three dimensions in one view (elevation). Jadi proyeksi isometris adalah gambar dari suatu objek dalam tiga bidang permukaan.

Gambar orthogonal adalah proyeksi yang memiliki bidang proyeksi yang tegak lurus terhadap proyektor (garisgaris bidang proyektor). Gambar proyeksi ortogonal biasanya memerlukan lebih dari satu bidang proyeksi. Proyeksi orthogonal ada dua yaitu proyeksi kuadran i dan proyeksi kuadran III. Proyeksi kuadran I memiliki penempatan pandangan kanan di sebelah kiri gambar pandangan depan dan pandangan atas di sebelah bawah pandangan depan. Proyeksi kuadran III memiliki penempatan pandangan kanan di sebelah kanan pandangan depan dan pandangan atas di sebelah pandangan depan.

Hasil observasi yang sudah dilakukan di SMK Semen Padang di kelas X diperoleh data rekapitulasi nilai siswa untuk Mata 
Diklat Gambar Sketsa yang dijelaskan pada Tabel 1. Tabel 1 menggambarkan masih rendahnya persentasi pencapaian nilai Mata Diklat Gambar Sketsa siswa kelas X Teknik Mesin (TM) 1. Berdasarkan KKM Mata Diklat Gambar Sketsa 80, terdapat 15 dari 20 orang siswa yang belum mampu mencapai kompetensi pembelajaran. Penyebab rendahnya pencapaian hasil belajar ini yaitu siswa tidak memahami konsep materi pembelajaran. Selain itu, kurangnya latihan yang diberikan kepada siswa membuat siswa malas mengulang pembelajaran. Dalam mengerjakan tugas, siswa yang tidak memahami materi pembelajaran ini hanya membuat gambar tanpa mengikuti langkah pengerjaan yang baik sehingga siswa tidak terampil dalam mengerjakan desain gambar. Dalam kegiatan pembelajaran masih banyak siswa yang keluar masuk ruangan kelas atau tidak mengikuti pembelajaran. Sebagian siswa tidak memahami materi pembelajaran dan belum mahir dalam menggunakan alat gambar. Akibat kurang aktifnya siswa dalam proses belajar ini berpengaruh terhadap hasil belajarnya.

Hasil belajar gambar teknik siswa kelas X Teknik Mesin SMK Semen Padang masih rendah. Rendahnya hasil belajar siswa di antaranya disebabkan karena masih belum bervariasinya metode pembelajaran yang dipergunakan guru di dalam kelas. Primawati, Ambiyar, dan
Ramadhani (2017) menjelaskan bahwa guru sebaiknya menggunakan model pembelajaran yang menyebabkan siswa aktif dalam pembelajaran. Salah satu model pembelajaran yang berpusat ke siswa (student centre learning) adalah model pembelajaran PjBL. Schuetz (2018) mengatakan "PjBL is an instructional approach designed to give students the opportunity to develop knowledge and skills through engaging projects set around challenges and problems they may face in the real world". Lebih lanjut Goodman dan Stivers (2010) mengatakan bahwa PjBL adalah a dynamic approach to teaching in which students explore real-world problems and challenges, simultaneously developing $21^{\text {st }}$ Century skills while working in small collaborative groups. Mengacu pada ketiga pendapat ini dapat ditarik suatu kesimpulan bahwa PjBL merupakan suatu pendekatan pembelajaran yang dapat digunakan oleh guru memberikan kesempatan bagi siswa dalam meningkatkan keterampilan yang sesuai dengan abad 21 dan pengetahuannya.

Model PjBL memiliki keunggulan di antaranya: dapat meningkatkan motivasi belajar siswa untuk melakukan pekerjaan/ tugas secara baik, dapat meningkatkan kemampuan penyelesaian masalah bagi siswa, memberikan pengalaman kepada siswa untuk mengorganisasikan proyek, dan mengalokasikan waktu untuk menyelesaikan

Tabel 1

Nilai Siswa Kelas X TM 1 TP 2017/2018 SMK Semen Padang

\begin{tabular}{cccc}
\hline No & Nilai & Jumlah Siswa & Persentase \\
\hline 1 & $20-39$ & 3 & $15 \%$ \\
2 & $40-59$ & 5 & $25 \%$ \\
3 & $60-79$ & 7 & $35 \%$ \\
4 & $80-99$ & 5 & $25 \%$ \\
\hline \multicolumn{4}{c}{ Total } \\
\hline \multicolumn{4}{c}{ Sumber: Guru Mata Diklat Gambar Sketsa SMK Semen Padang }
\end{tabular}


proyek, meningkatkan keterampilan siswa terhadap kompetensi pembelajaran yang ingin dicapai, dan melatih siswa untuk aktif dalam kegiatan pembelajaran (Sani, 2014, p. 177). Penekanan pada pembelajaran PjBL ini adalah aktivitas belajar siswa untuk menerapkan keterampilan meneliti, menganalisis, membuat, dan mempresentasikan produk dalam kegiatan pembelajaran.

Langkah-langkah dalam penerapan model PjBL yaitu: menentukan pertanyaan mendasar, mendesain perencanaan proyek, menyusun jadwal pengerjaan, me-monitoring kemajuan proyek, penilaian hasil proyek, dan evaluasi pelaksanaan model pembelajaran. Dalam kegiatan penerapan model $\mathrm{PjBL}$, guru memiliki peranan sebagai motivator yang mendorong dan membimbing siswa untuk mengembangkan keterampilan dan pengetahuannya dalam pengerjaan tugas. Selanjutnya, dalam penerapan model PjBL guru berfungsi sebagai fasilitator yang memberikan kesempatan dan fasilitas belajar yang nyaman bagi siswa.

Beberapa penelitian sudah dilakukan terkait dengan penerapan PjBL. Hasil penelitian menunjukkan $\mathrm{PjBL}$ dapat meningkatkan keaktifan dan hasil belajar siswa (Saputra, 2016a) dan kompetensi Computerised Aided Design (CAD) siswa SMK (Saputra, 2016b), memiliki efek positif pada keterlibatan siswa, motivasi, dan keyakinan siswa dengan kemampuan mereka sendiri (Condliffe, et al., 2017). Temuan penelitian Muskania dan Wilujeng (2017) menunjukkan perangkat pembelajaran berbasis PjBL memberikan pengaruh signifikan terhadap scientific literacy peserta didik.

Tujuan penelitian ini adalah untuk meningkatkan motivasi belajar siswa, keterampilan siswa melalui penerapan model, dan hasil belajar siswa melalui penerapan model PjBL pada Mata Diklat Gambar Sketsa di Kelas X TM 1.

\section{METODE}

Jenis penelitian ini adalah penelitian tindakan kelas (action research). Action research is done by teachers in their own classrooms with the goal of improving pedagogy and student learning (Phillips \& Carr, 2014; Norton, 2009). Penelitian ini dilakukan pada bulan Februari-Agustus 2018. Penelitian dilakukan dalam dua siklus dengan jumlah siswa 20 orang. Ada beberapa tahapan dalam penelitian ini, dimulai dengan tahap persiapan, pelaksanaan penelitian, pengolahan data, dan penarikan kesimpulan.

Pada tahap persiapan melakukan koordinasi dengan guru Mata Diklat Gambar Sketsa di SMK Semen Padang. Peneliti menyusun perencanaan penelitian, RPP, instrumen penilaian, dan proses penerapan PjBL untuk Mata Diklat Gambar Sketsa. Instrumen penilaian yang digunakan dalam penelitian ini lembar observasi, lembar tes objektif, dan lembar penilaian proyek siswa (rubrik).

Lembar observasi berfungsi untuk mengamati motivasi belajar siswa selama mengikuti pembelajaran. Indikator dari motivasi belajar mengacu pada indikator motivasi Keller (2010) yaitu: Attention, Relevance, Confidence, dan Satisfaction (ARCS). Kategori dari motivasi belajar siswa mengacu pada Tabel 2.

Lembar tes objektif berfungsi untuk melihat hasil belajar tentang pemahaman dan pengetahuan siswa terkait materi Gambar Sketsa yang sudah dipelajari. Selanjutnya lembar penilaian proyek berfungsi untuk melihat peningkatan pencapain keterampilan menggambar benda, komunikasi, dan kerja kelompok siswa di setiap pertemuan pembelajaran. 
Tabel 2

Kategori Keaktifan siswa

\begin{tabular}{cll}
\hline No & \multicolumn{1}{c}{$\begin{array}{c}\text { Rentang } \\
\text { Nilai }\end{array}$} & \multicolumn{1}{c}{ Kategori } \\
\hline 1 & $\geq 90$ & Sangat tinggi \\
2 & $80-89$ & Tinggi \\
3 & $70-79$ & Cukup tinggi \\
4 & $60-69$ & Rendah \\
5 & $<59$ & Sangat rendah \\
\hline
\end{tabular}

Summber: Modifikasi Aqib (2009, p. 41)

Sebelum melakukan penelitian di kelas X TM1 peneliti melakukan uji coba instrumen penelitian pada kelas X TM 2 yang memiliki rata-rata kelas yang hampir sama dengan kelas penelitian. Hasil uji coba instrumen penelitian diperoleh data validitas soal objektif, tingkat kesukaran, dan daya beda soal. Arikunto (2013, p. 75) menyatakan rumus yang digunakan untuk menentukan tingkat validitas butir soal digunakan rumus (1).

$$
r_{x y}=\frac{N \sum X Y-\left(\sum X\right)\left(\sum Y\right)}{\sqrt{\left(\left(N \sum X^{2}-\left(\sum X\right)^{2}\right)\left(N \sum Y^{2}-\left(\sum Y\right)^{2}\right)\right)}}(1)
$$

Keterangan:

$r_{X Y}$ : koefisien korelasi

$X$ : skor item (soal)

$Y \quad$ : skor total yang diperoleh

Hasil uji validitas soal pada uji coba instrumen dengan bantuan analisis program anates versi 4.02 , terdapat 32 butir soal yang valid dari 40 butir soal. Selanjutnya, butir soal dianalisis tingkat kesukarannya. Latisma (2011, p. 156) untuk tingkat kesukaran soal digunakan rumus (2).

$$
P b=\frac{B-S / a-1}{B+S}(2)
$$

Keterangan:

$\mathrm{Pb}$ : angka indeks kesukaran

B : jumlah peserta tes menjawab benar

$\mathrm{S}$ : jumlah peserta tes menjawab salah

a : jumlah alternatif jawaban pada tes
Hasil uji coba instrumen yang dianalisis dengan bantuan anates versi 4.02 terkait dengan indek kesukaran diperoleh hasil 5 soal dinyatakan sukar, yaitu soal nomor 3 , $9,12,21$, dan 28 . Soal yang dinyatakan mudah nomor 10,15 , dan 26. Selebihnya ada 32 butir soal yang dinyatakan memiliki indek kesukaran dalam kategori sedang.

Untuk melihat kemampuan soal dalam membedakan kemampuan siswa antara siswa yang berkemampuan tinggi dan rendah digunakan daya beda soal. Ambiyar (2012, p. 155) menjelaskan bahwa daya beda butir soal menggunakan rumus (3).

$$
D=P H D=P H-P L(3)
$$

Keterangan:

$D=$ Indeks Diskriminasi

$P H=$ Proporsi kelompok atas

$P L=$ Proporsi kelompok bawah

Hasil analisis data terhadap daya beda soal untuk uji soal intrumen dapat dideskripsikan dalam kategori jelek, cukup, baik, dan baik sekali. Sesudah pengolahan data ini didapatkan, soal dapat dibagikan kepada siswa dalam penelitian pada akhir siklus satu dan kedua. Pada penyusunan soal di siklus satu dan dua, soal yang digunakan diacak untuk menghindari kebosanan siswa dalam mengerjakan soal yang sama. Daya beda soal uji coba instrumen diperoleh hasil tiga soal dinyatakan dengan daya beda yang jelek, yaitu nomor soal 12, 21, dan 28. Soal dengan daya beda cukup (sedang) sebanyak 5 butir soal yaitu butir soal nomor 3, 9, 10, 15, dan 26. Selebihnya ada 32 butir soal yang dinyatakan dengan daya beda baik dan sangat baik. Butir soal yang memiliki indek kesukaran yang sedang dan daya beda yang baik digunakan sebagai tes untuk mengukur pengetahuan (kompetensi) siswa dalam Mata Diklat Gambar Sketsa. 
Penilaian proyek siswa dilakukan dengan mengamati siswa dalam menggunakan alat gambar, menganalisis benda menjadi gambar kerja dalam bentuk gambar orthogonal, dan kesesuaian ukuran benda kerja dengan gambar yang sudah dirancang. Penilaian proyek siswa meliputi aspek keterampilan: menyiapkan alat praktikum, ketekunan dalam bekerja, pengelolaan waktu kerja, kerja sama, komunikasi, kebersihan pekerjaan praktikum, tanggung jawab, dan hasil (Arikunto, 2013, p. 183). Setiap aspek diberi bobot penilain $1=$ sangat kurang, $2=$ kurang, $3=$ cukup, $4=$ baik, dan $5=$ baik sekali.

Pengukuran ranah psikomotorik siswa dimulai dengan mengukur ranah kognitif siswa misalnya, melihat keterampilan siswa menggunakan alat gambar seiring dengan pengetahuan siswa tentang fungsi dan cara menggunakan alat gambar (Arikunto, 2013, p.182). Penilaian terhadap keterampilan siswa memiliki dua karakter yaitu, penilaian kemampuan siswa mengerjakan produk dan penilaian hasil produk (Sani, 2016, p. 229).

Aspek penilaian pada tugas dan latihan Gambar Sketsa adalah kebersihan lembar kerja, kejelasan garis benda, garis proyeksi benda, ketepatan ukuran gambar benda. Data dianalisis dengan menggunakan statistik deskriptif. Hasil analisis data akan menggambarkan kemampuan siswa dalam mencapai KKM Mata Diklat Gambar Sketsa yang sudah ditetapkan yaitu 80. Melalui analisis data juga akan terlihat penerapan PjBL dapat meningkatkan keterampilan dan hasil belajar siswa atau tidak.

\section{HASIL PENELITIAN DAN PEMBAHASAN}

Penelitian tindakan kelas ini dilakukan selama dua siklus. Setiap siklus terdapat dua kali pertemuan. Tahapan di setiap siklusnya yaitu perencanaan, tindakan, dan observasi, refleksi, dan tindak lanjut terhadap hasil penelitian yang sudah dilakukan. Kegiatan pertama yang dilakukan pada penelitian adalah menentukan kelas penelitian. Dalam menentukan kelas penelitian dilakukan pretest di kelas X TM SMK Semen Padang. Berdasarkan hasil pretest dan saran dari guru Mata Diklat Gambar Sketsa di SMK Semen Padang, kelas yang digunakan pada penelitian adalah kelas X TM1. Berdasarkan hasil analisis terdapat $40 \%$ dari jumlah siswa yang mampu mencapai KKM Gambar Sketsa yaitu 80.

Penelitian pada siklus pertama dilakukan dalam dua kali pertemuan. Kegiatan perencanaan siklus satu yaitu mempersiapkan materi pembelajaran, RPP, dan instrumen penilaian. Kegiatan tindakan yaitu menjalankan RPP dan melakukan penilaian sesuai dengan instrumen penilaian yang sudah disusun. Sesudah guru selesai menyampaikan materi pembelajaran, siswa dibagi menjadi lima kelompok dengan anggota empat orang siswa.

Sintak 1 (menyampaikan pertanyaan mendasar), pada kegiatan ini guru menyampaikan pertanyaan misalnya, "Bagaimana bentuk perancangan palu? Apa fungsi dari palu ?". Sintak 2 dan 3 (mendesain perencanaan proyek dan waktu pengerjaan), siswa dibimbing untuk mengelola anggota kelompok, membagi tugas untuk setiap anggota dan merancang waktu pengerjaan tugas jumlah tugas perancangan benda yang akan dikerjakan siswa adalah tiga gambar benda kerja. Sintak 4 (monitoring) guru melakukan monitoring dan bimbingan terhadap setiap kelompok, melakukan observasi terhadap kegiatan pembelajaran dan keterampilan siswa dalam menyelesaikan tugas. Sintak 5 (penilain), dalam kegiatan penilain siswa secara berkelompok mempresentasikan hasil perencanaan benda kerja di depan kelas, siswa menjelaskan fungsi dari benda kerja. Untuk mengukur pengetahuan siswa dilakukan penilaian kognitif dengan lembar 
tes objektif dan penilaian proyek dengan instrumen penilain proyek yang sudah disusun.

Dalam kegiatan observasi di Siklus 1 didapatkan hal sebagai berikut: guru mata diklat melaksanakan pembelajaran sesui dengan RPP, masih terdapat siswa yang tidak membawa perlengkapan gambar dengan lengkap, masih terdapat siswa yang belum menguasai materi pembelajaran, terdapat siswa yang belum mahir menggunakan alat gambar, siswa belum mampu membedakan penggunaan ketebalan garis pada gambar, siswa tidak memperhatikan kebersihan kertas gambar, ketekunan siswa dalam mengerjakan tugas masih rendah, belum mandirinya siswa, masih banyak siswa hanya mengandalkan teman kelompoknya dalam mengerjakan tugas, dan kurangnya alokasi waktu dalam kegiatan pembelajaran.

Kegiatan refleksi pada siklus pertama, dari aplikasi model PjBL didapatkan pencapain hasil belajar siswa mencapai $50 \%$ dari jumlah siswa mencapai KKM, serta penilaian keterampilan mencapai 55\% dari jumlah siswa mencapai KK. Namun, hal ini belum dapat mencapai indikator keberhasilan yang sudah ditetapkan sebelumnya yaitu $60 \%$ dari siswa yang mencapai KKM pada Mata Diklat Gambar Sketsa. Kegiatan tindak lanjut bagi siswa agar dapat mencapai KKM yang sudah ditetapkan dilakukan pengayaan dan bimbingan secara individual bagi siswa yang kurang memahami dan tidak terampil dalam menggunakan alat gambar oleh guru Mata Diklat Gambar Sketsa. Di samping bimbingan dan pengayaan, siswa dianjurkan meningkatkan kerja sama dalam mengerjakan tugas proyek dan saling berbagi pengetahuan terkait pembelajaran gambar orthogonal dan piktorial. Selanjutnya, penelitian ini dilanjutkan pada siklus kedua dengan melakukan perencanaan tindak lanjut untuk memperbaiki kekurangan pada siklus pertama.

Siklus kedua, dilaksanakan dalam dua kali pertemuan. Kegiatan awal pada siklus kedua ini adalah perencanaan. Pada kegiatan perencanaan ini guru mempersiapkan RPP, instrumen penilaian, dan materi pembelajaran. Langkah tindakan, dalam langkah ini kegiatan yang dilakukan adalah pembagian anggota kelompok sesuai dengan kelompok pada siklus pertama, membimbing siswa merancang proyek secara kelompok dan membimbing siswa, me-monitoring kegiatan belajar. Sesuai dengan hasil diskusi dan mempertimbangkan kendala yang dihadapi pada siklus pertama yaitu alokasi waktu pengerjaan tugas yang tidak cukup bagi siswa dalam mengerjakan perancanagn benda maka, jumlah tugas pada siklus kedua menjadi dua gambar kerja

Kegiatan observasi, dalam kegiatan pengamatan kegiatan belajar ini didapatkan peningkatan pencapaian siswa yaitu: siswa sudah mulai terampil dalam menganalisis benda kerja ke dalam bentuk gambar benda, adanya kerja sama yang positif antara siswa dalam kelompok, hasil gambar siswa sudah terlihat rapi, dan siswa sudah mulai mahir dalam menggunakan alat gambar.

Kegiatan refleksi pada siklus kedua ini didapatkan hasil belajar siswa mencapai $80 \%$ dari jumlah siswa mencapai KKM, dan pencapain keterampilan siswa $75 \%$ dari jumlah siswa mencapai KKM Gambar Sketsa. Jika diukur dengan indikator keberhasilan yang sudah dirancang hasil ini sudah mencapai indikator keberhasilan siklus kedua yaitu 70\% dari jumlah siswa mencapai KKM. Kegiatan tindak lanjut bagi siswa yang belum mencapai KKM yang sudah ditetapkan dilakukan pengayaan dan bimbingan secara individual bagi siswa yang kurang memahami dan tidak terampil dalam menggunakan alat gambar oleh guru Mata Diklat Gambar Sketsa. 
Hasil pengolahan data untuk motivasi belajar siswa dengan penerapan model PjBL pada Mata Diklat Gambar Sketsa dicantum pada Tabel 3. Siklus 1 pada Tabel 3 menunjukkan skor rata-rata indikator perhatian sebesar 69,05 dengan kategori rendah; relevansi sebesar 77,35 dengan kategori cukup tinggi; konfiden sebesar 67,65 dengan kategori rendah; dan kepuasan sebesar 70,7 dengan kategori cukup tinggi. Sementara itu, skor rata-rata motivasi belajar siswa secara keseluruhan sebesar 71,24 dengan kategori cukup tinggi. Pada siklus 2, skor rata-rata motivasi belajar siswa untuk indikator perhatian sebesar 85,5 dengan kategori tinggi; indikator relevansi sebesar
88,6 dengan kategori tinggi; konfiden sebesar 82,55 dengan kategori tinggi; dan kepuasan sebesar 87,15 dengan kategori tinggi karena memiliki skor $>80$. Begitu pula dengan skor rata-rata motivasi belajar siswa secara keseluruhan sebesar 85,34 dengan kategori tinggi. Meskipun turorial belajar dari guru memiliki skor 78,25 dengan kategori cukup.

Hasil pengolahan data untuk penilaian psikomotorik (keterampilan) siswa yaitu dalam bentuk pengisian instrumen penilaian proyek. Sesudah penerapan model PjBL dan dilakukan penilaian keterampilan pada siswa pada Mata Diklat Gambar Sketsa didapatkan data seperti tercantum pada Tabel 4.

Tabel 3

Ketercapaian Indikator Motivasi Belajar Siswa

\begin{tabular}{|c|c|c|c|c|c|c|}
\hline \multirow{2}{*}{ No } & \multirow{2}{*}{ Indikator } & \multirow{2}{*}{ Pernyataan } & \multicolumn{2}{|c|}{ Siklus 1} & \multicolumn{2}{|c|}{ Siklus 2} \\
\hline & & & Skor & Kategori & Skor & Kategori \\
\hline \multirow[t]{2}{*}{1} & Perhatian & Hasrat dan keinginan berhasil & 72,6 & Cukup & 88,7 & Tinggi \\
\hline & & $\begin{array}{l}\text { Lingkungan belajar yang } \\
\text { kondusif }\end{array}$ & 65,5 & Rendah & 82,4 & Tinggi \\
\hline \multirow[t]{2}{*}{2} & Relevansi & $\begin{array}{l}\text { Relevansi pembelajaran dengan } \\
\text { kebutuhan }\end{array}$ & 78,9 & Cukup & 89,3 & Tinggi \\
\hline & & Pembelajaran yang konstektual & 75,8 & Cukup & 87,9 & Tinggi \\
\hline \multirow[t]{2}{*}{3} & Konfiden & $\begin{array}{l}\text { Kemampuan yang dimiliki } \\
\text { dalam mengerjakan tugas }\end{array}$ & 72,6 & Cukup & 86,9 & Tinggi \\
\hline & & Tutorial belajar dari guru & 62,7 & Rendah & 78,2 & Cukup \\
\hline \multirow[t]{3}{*}{4} & Kepuasan & $\begin{array}{l}\text { Diskusi dan saling berbagi } \\
\text { pengetahuan antarteman }\end{array}$ & 63,8 & Rendah & 86,1 & Tinggi \\
\hline & & Penghargaan dalam belajar & 77,6 & Cukup & 88,2 & Tinggi \\
\hline & & $\begin{array}{l}\text { Skor rata-rata motivasi belajar } \\
\text { siswa }\end{array}$ & 71,2 & Cukup & 85,9 & Tinggi \\
\hline
\end{tabular}

Tabel 4

Nilai Keterampilan Siswa pada Penelitian

\begin{tabular}{lcc}
\hline & Siklus 1 & Siklus 2 \\
\hline Jumah Siswa yang Tuntas & 11 & 16 \\
Rata-rata Kelas & 78,67 & 83,65 \\
Persentase Ketuntasan & $55 \%$ & $80 \%$ \\
\hline
\end{tabular}


Siklus 1 pada Tabel 4 menunjukkan bahwa jumlah siswa yang tuntas ada 11 dan siswa yang belum tuntas ada 9 karena jumlah semua. siswa ada 20 dengan nilai rata-rata keterampilan sebesar 78,67. Nilai keterampilan tertinggi 88 dan yang terendah 53; simpangan baku 9,96; dan varians 99,25 . Sesudah dilakukan refleksi pada siklus 1 dalam menerapkan model pembelajaran PjBL, maka pada siklus 2 diperoleh nilai keterampilan siswa yang tuntas ada 16 dan belum tuntas 4 siswa. Nilai rata-rata keterampilan siswa 83,65 ; dengan skor tertinggi 93; dan terendah 73 ; simpangan baku 6,91 dan varians 47,734.

Hasil belajar siswa pada Mata Diklat Gambar Sketsa dengan penerapan model PjBL diukur dengan melakukan penilaian yang berkaitan dengan aspek kognitif (pengetahuan) menggunakan tes objektif pilihan ganda sehingga didapatkan hasil seperti tercantum pada Tabel 5.

Siklus 1 pada Tabel 5, jumlah siswa yang tuntas ada 10 dan siswa yang belum tuntas ada 10 karena jumlah semua. siswa ada 20 dengan nilai rata-rata hasil belajar sebesar 75,95. Nilai hasil belajar tertinggi 87 dan yang terendah 53; simpangan baku 8,73; dan varians 76,16. Sesudah dilakukan refleksi pada siklus 1 dalam menerapkan model PjBL, maka pada siklus 2 diperoleh nilai hasil belajar siswa yang tuntas ada 16 dan belum tuntas 4 siswa. Nilai rata-rata keterampilan siswa 85,45 ; dengan skor tertinggi 93; dan terendah 70; simpangan baku 6,81 dan varians 46,26 .
Keterampilan siswa dapat ditingkatkan dengan penerapan model PjBL, keterampilan menggunakan alat gambar pada siswa meningkat di setiap pertemuan. Hal ini karena adanya latihan dari siswa sehingga terbiasa dalam menggunakan alat gambar. Terlihat peningkatan pengetahuan dan pemahaman siswa tentang materi Orthogonal karena adanya kegiatan diskusi dan presentasi di depan kelas yang dilakukan oleh siswa sehingga kekurangan pada gambar kerja dapat dilihat dan dipelajari secara bersama.

Temuan penelitian menunjukkan terdapat peningkatan motivasi belajar siswa pada Mata Diklat Gambar Sketsa dengan penerapan model pembelajaran based learning. Dalam kegiatan belajar diperlukan adanya motivasi. Adanya motivasi dapat memacu semangat siswa dalam belajar sehingga akan memperoleh keberhasilan. Sebaliknya siswa yang termotivasi dalam belajar akan memperoleh hasil yang kurang memuaskan. Motivasi berperan penting dalam menentukan keberhasilan belajar siswa sehingga diperlukan perhatian dan upaya dari guru untuk mendorong semangat belajar siswa (Handayani, 2017)

Motivasi belajar siswa pada siklus 1 dalam kategori cukup tinggi. Walaupun begitu ada dua indikator dari motivasi yang memiliki skor dengan kategori rendah, yaitu perhatian dan konfiden. Perhatian dan keinginan berhasil bagi siswa dalam pembelajaran Gambar Sketsa belum tinggi. Dengan menerapkan model

Tabel 5

Nilai Hasil Belajar Siswa

\begin{tabular}{lccc}
\hline & Prates & Siklus 1 & Siklus 2 \\
\hline Jumah Siswa yang Tuntas & 8 & 10 & 16 \\
Rata-rata Kelas & 70,60 & 75,95 & 85,45 \\
Persentase Ketuntasan & $40 \%$ & $50 \%$ & $80 \%$ \\
\hline
\end{tabular}


PjBL, guru sudah menjelaskan tentang konsep materi, memberikan latihan dalam membuat gambar sketsa dan penggunaan alat gambar agar mahir, mengulang pembelajaran yang sulit untuk diselesaikan oleh siswa sehingga menyebabkan siswa lebih aktif dalam belajar dan motivasi belajar siswa menjadi tinggi pada siklus 2. Meskipun tutorial belajar dari guru memiliki skor 78,25 dalam kategori cukup tinggi, akan tetapi siswa sudah menunjukkan motivasi belajar yang tinggi. Di samping itu, peran guru memang sebagai fasilitator dan tutorial untuk model pembelajaran yang berpusat kepada siswa. Rochayati dan Wardani (2018) menjelaskan peran guru dalam mengimplementasikan pembelajaran yaitu: sebagai fasilitator, supervisor, motivator, dan evaluator.

Motivasi bisa berasal dari dalam diri siswa (internal). Keinginan sukses dalam belajar yang berasal dari dalam diri siswa, siswa lebih memiliki motivasi yang tinggi. Siswa dengan motivasi tinggi berusaha mengerjakan dan menyelesaikan tugas yang diberikan oleh guru kepadanya. Siswa akan berusaha belajar semaksimal mungkin untuk diri sendiri maupun bersaing dengan teman yang lain. Bila siswa kurang memahami konsep materi pembelajaran dan tugas yang diberikan guru, maka siswa bertanya kepada guru dan berdiskusi dengan teman sebayanya. Guru dapat juga memberikan motivasi kepada siswanya sebagai faktor internal. Guru dapat memberikan bimbingan, latihan, dan menjelaskan kepada siswanya agar kemampuan (kompetensi) dapat meningkat. Guru dapat menerapkan model pembelajaran yang bervariasi, sehingga pembelajaran lebih menarik dan motivasi belajar lebih meningkat. Terbukti dengan penerapan model PjBL dapat meningkatkan motivasi belajar siswa.
Siswa memiliki pemahaman dan kemampuan tentang dirinya sendiri. Di sekolah atau di dalam kelas ada kemungkinan kemampuan yang dimiliki oleh siswa sulit terlihat oleh guru. Karakteristik dan kemampuan siswa perlu diketahui oleh guru, karena akan mempengaruhi aktivitas belajar siswa. Interaksi siswa dengan gurunya, teman sebaya, dan orang dewasa lain, akan mempengaruhi hasil belajarnya.

Siswa sudah memiliki gambaran tentang dirinya, sewaktu datang ke sekolah. Walaupun begitu, adanya guru akan mempengaruhi dan membentuk gambaran tentang diri siswa. Guru dengan profesionalisme yang tinggi akan berusaha mengembangkan segala kompetensinya guna memenuhi kebutuhan siswa dalam belajar yang menyenangkan dan tidak membosankan (Syamsuriyanti \& Sukirno, 2018). Kehadiran guru bertujuan untuk membantu siswa dalam mencapai gambaran dirinya kearah yang positif, sekaligus dapat meningkatkan motivasi belajarnya. Nilai rata-rata motivasi belajar siswa pada siklus 1 sebesar 71,24 dan meningkat menjadi 85,34 pada siklus 2 .

Hasil penelitian juga menunjukkan terdapat peningkatan keterampilan siswa dalam Mata Diklat Gambar Sketsa dengan penerapan model pembelajaran based learning. Belajar merupakan suatu usaha dari seseorang untuk memperoleh ilmu pengetahuan dan keterampilan. Kunandar (2013, p. 62) menyebutkan bahwa hasil belajar adalah kompetensi atau kemampuan tertentu baik kognitif, afektif ataupun psikomotorik yang dikuasai peserta didik sesudah mengikuti proses belajar mengajar. Evaluasi pembelajaran diperlukan untuk mengetahui pencapain belajar. Perubahan pengetahuan siswa dapat diukur dengan melakukan evaluasi berkaitan dengan pengetahuan dan pemahaman siswa terhadap pembelajaran. Perubahan 
keterampilan siswa dapat diukur dengan melakukan penilaian dan pengamatan yang dapat dideskripsikan dalam kalimat terampil dan tidak terampil.

Keterampilan merupakan kemampuan yang dimiliki oleh seseorang melalui usaha yang sistematis sehingga dapat menggunakan ide dan kreatifitas dalam melakukan suatu pekerjaan. Untuk melatih tingkat keterampilan siswa, dapat dilakukan penilaian keterampilan siswa melalui kerja praktik, pembuatan karya, dan penilaian lainnya. Kamdi (2010) menyebutkan bahwa aspek keterampilan yang dapat dikembangkan melalui kerja proyek adalah kemampuan menggunakan alat dasar, bekerja dalam tim, kemampuan memanfaatkan berbagai informasi sehingga tugas proyek dapat memberikan latihan kepada siswa untuk mengembangkan keterampilan. Keunggulan dari model PjBL dapat meningkatkan keterampilan siswa terhadap kompetensi pembelajaran yang ingin dicapai dan melatih siswa untuk aktif dalam kegiatan pembelajaran, di samping beberapa keunggulan lainnya (Sani, 2014)

Aplikasi model PjBL dapat meningkatkan keterampilan dan hasil belajar gambar sketsa siswa SMK Semen Padang. Ini berarti penerapan model $P j B L$ memiliki keuntungan bagi siswa dalam pembelajaran gambar sketsa. Penerapan $P j B L$ dapat meningkatkan keterampilan siswa terhadap kompetensi pembelajaran yang ingin dicapai, di samping beberapa keuntungan lainnya (Sani, 2014; Griva, Semoglou, \& Geladari, 2010). PjBL menunjukkan efek positif terhadap hasil belajar siswa (Chu, Tse, \& Chow, 2011)

Penerapan model PjBL pada siklus 1 masih terlihat kecanggungan siswa dalam mengerjakan tugas. Terlihat siswa masih bingung untuk mengerjakan perancangan gambar benda. Sesudah diberikan penjelasan dengan bantuan benda kerja yang sudah ada dan bimbingan, siswa kebingungan siswa mulai berkurang dalam menyelasaikan tugas proyeknya. Pada siklus 1 ini siswa belum dapat mencapai ketuntasan $60 \%$ sesuai dengan perencanaan.

Sesudah melakukan refleksi pada siklus 1, pada siklus 2 ini terlihat perbaikan dalam cara belajar siswa. Siswa sudah mengerjakan tugas proyeknya sesuai dengan yang ditetapkan. Kesalahan yang terjadi pada lembar tugas pada pertemuan sebelumnya sudah diperbaiki dan dilengkapi. Pada siklus 2 ini siswa sudah mencapai indikator keberhasilan 70\%. Keterampilan siswa dapat ditingkatkan dengan mengaplikasikan penerapan model PjBL. Keterampilan menggunakan alat gambar siswa semakin baik pada setiap pertemuannya. Hal ini terlihat pada hasil gambar siswa, kejelasan menggunakan garis, ukuran, huruf, dan angka. Kemampuan menyampaikan pendapat siswa semakin baik. Siswa sudah menggunakan bahasa yang mudah dimengerti untuk menyampaikan maksud perancangan gambar yang sudah dirancang. Nilai rata-rata kelas keterampilan siswa pada siklus 1 sebesar 78,67 dan meningkat sebesar 83,50 pada siklus 2 .

Siswa untuk dapat bekerja sama dalam hal yang positif melalui penerapan model pembelajaran PjBL. Siswa dapat berbagi pengetahuan, tanpa berbuat curang atau mencontek kepada teman, siswa dapat berdiskusi dan saling memberi masukan terkait materi pembelajaran gambar sketsa sehingga siswa dapat meningkatkan pemahaman terkait pembelajaran yang sudah diberikan. Hal ini terlihat dari hasil belajar siswa yang meningkat dalam setiap siklus penelitian. Nilai rata-rata kelas keterampilan siswa pada siklus 1 sebesar 78,67 dan meningkat sebesar 83,50 pada siklus 2. Dari hasil penerapan PjBL tersebut dapat menjadi kebiasaan pendidik dalam menerapkan berbagai 
model pembelajaran dan pengalaman belajar. Seperti yang diungkapkan Syahri, Syahril, dan Yuliana (2015) menyatakan pendidik harus menciptakan peluang berbagai pengalaman belajar yang dapat dilalui siswa untuk membantu tercapainya pengalaman belajar yang optimal bagi siswa.

Penelitian yang sudah dilakukan ini mendukung temuan penelitian lain bahwa PjBL has been shown to be more effective than traditional methods (Finkelstein, Hanson, Huang, Hirschman, \& Huang, 2010; Parker et al., 2011; Jensen, 2015). Bell (2010) menjelaskan bahwa Projectbased learning is an innovative approach to learning that teaches a multitude of strategies critical for success in the twenty-first century. Hasil penelitian ini juga mendukung temuan penelitian yang menyatakan in project-based learning, students gain important knowledge, skills, and dispositions by investigating openended questions to "make meaning" that they transmit in purposeful ways (Krauss \& Boss, 2013, p. 5)

\section{SIMPULAN}

Berdasarkan penelitian yang sudah dilakukan diperoleh kesimpulan: pertama, adanya peningkatan motivasi belajar siswa dengan penerapan model PjBL. Motivasi belajar siswa pada siklus 1 memperoleh skor rata-rata 71,24 dengan kategori cukup tinggi dan skor rata-rata 85,34 pada siklus 2 dengan kategori tinggi. Kedua, adanya peningkatan keterampilan pada siswa dengan penerapan model PjBL. Peningkatan keterampilan ini terlihat pada siklus 1 sebanyak $55 \%$ dari jumlah siswa atau 11 dari 20 orang siswa mencapai KKM 80 Mata Diklat Gambar Sketsa, meningkat pada siklus 2 menjadi $75 \%$ atau 15 dari 20 orang siswa mencapai KKM. Ketiga, terjadinya peningkatan hasil belajar pada siswa dengan penerapan model PjBL. Peningkatan hasil belajar ini terlihat pada siklus 1 sebanyak $50 \%$ dari jumlah siswa atau 10 dari 20 orang siswa mencapai KKM 80 Mata Diklat Gambar Sketsa, meningkat pada siklus 2 menjadi $80 \%$ atau 16 dari 20 orang siswa mencapai KKM.

Sesudah melakukan penelitian penerapan model PjBL di SMK Semen Padang memberikan saran sebagai berikut. pertama, model PjBL merupakan salah satu model pembelajaran alternatif yang dapat diterapkan oleh guru untuk meningkatkan motivasi belajar, keterampilan, dan hasil belajar siswa pada mata diklat produktif di pendidikan vokasi, misalnya pada Mata Diklat Gambar Sketsa. Kedua, model PjBL ini dapat menjadi acuan bagi peneliti berikutnya untuk meneliti pada variabel kerja sama siswa (collaborative), komunikatif antarsiswa (communicative), kemampuan siswa dalam memecahkan masalah (problem solving), kreativitas, dan lainnya serta pada mata diklat yang berbeda dalam pendidikan kejuruan.

\section{DAFTAR PUSTAKA}

Ambiyar, (2012). Pengukuran dan tes dalam pendidikan. Padang: UNP Press.

Aqib, Z. (2009). Penelitian tindakan kelas untuk guru SD, SLB, dan TK. Bandung: Yrama Widya.

Arikunto, S. (2013). Dasar-dasar evaluasi pendidikan (Edisi Revisi). Jakarta: Bumi Aksara.

Bell, S. (2010). Project-based learning for the $21^{\text {st }}$ Century: Skills for the future. The Clearing House, 83, 39-43. Diunduh dari https://files.eric.ed.gov/ fulltext/ED578933.pdf

Chu, S. K. W., Tse, S. K., \& Chow, K. (2011). Using collaborative teaching and inquiry project-based learning to help primary school students develop 
information literacy and information skills. Library \& Information Science Research, 33(2), 132-143.

Condliffe, B., Quint, J., Visher, M. G., Bangser, M. R., Drohojowska, S., Saco, L., \& Nelson, E. (2017). Projectbased learning a literature review. Working paper. New York: MDRC.

Finkelstein, N., Hanson, T., Huang, C-W., Hirschman, B., \& Huang, M. (2010). Effects of problem based economics on high school economics instruction. California. Institute of Education Sciences

Giesecke, F. E., Mitchell, A., Spencer, H., Hill, I., Dygdon, J., \& Novak, J. (2016). Technical drawing with engineering graphics. New York: Prentice Hall.

Goodman, B., \& Stivers, J. (2010). Project-based learning. Educational psychology, 2010, 1-8. Diunduh dari http://www.fsmilitary.org/pdf/Project Based_Learning.pdf.

Griva, E., Semoglou, K., \& Geladari, A. (2010). Early foreign language learning: Implementation of a project in a game-based context. ProcediaSocial and Behavioral Sciences, 2(2), 3700-3705.

Handayani, R. D. (2017). Analisis motivasi intrinsik dan ekstrinsik mahasiswa calon guru fisika. Jurnal Kependidikan, 1(2), 320-333.

Jensen, K. J. (2015). A meta-analysis of the effects of problem- and project-based learning on academic achievement in grades 6-12 populations. Education Dissertations, 7. Diunduh dari https:// digitalcommons.spu.edu/soe_etd/7/.

Kamdi. (2010). Implementasi PjBL di sekolah menengah kejuruan. Jurnal Pendidikan dan Pembelajaran, 7(1), 98-110.
Keller, J. M. (2010). Motivational design for learning and performance: The ARCS model approach. New York, NY: Springer. doi:10.1007/978-14419-1250-3

Krauss, J., \& Boss, S. (2013). Thinking through project-based learning. London: SAGE Publications Ltd.

Kunandar. (2013). Penilaian autentik (Penilaian hasil belajar peserta didik berdasarkan Kurikulum 2013). Jakarta: Rajawali Pers.

Latisma, D. (2011). Evaluasi pendidikan. Padang: UNP Press.

Madsen, D. A., \& Madsen, D. P. (2012). Engineering drawing \& design. Australia: Delmar, Cengage Learning.

Muskania, R. T., \& Wilujeng, I. (2017). Pengembangan perangkat pembelajaran project-based learning untuk membekali foundational knowledge dan meningkatkan scientific literacy. Cakrawala Pendidikan, 36(1), 34-43.

Parker, W. C., Mosborg, S., Bransford, J., Vye, N., Wilkerson, J., \& Abbott, R. (2011). Rethinking advanced high school coursework: Tackling the depth/breadth tension in the AP US government and politics course. Journal of Curriculum Studies, 43(4), 533-559.

Phillips, D. K., \& Carr, K. (2014). Becoming a teacher through action research. Process, context, and self-study. New York: Routledge.

Primawati, Ambiyar, \& Ramadhani, D. (2017). Peningkatan aktivitas dan hasil belajar siswa menggunakan metode talking stick. Jurnal Inovasi Vokasional dan Teknologi, 17(1), 7380. https://doi.org/10.24036/invotek/ vol17-iss1/23.

Rathnam, K. (2018). A first course in engineering drawing. Singapore: Springer Nature Singapore Pte Ltd. 
Rochayati, U., \& Wardani, R. (2018). Model pembelajaran karakter kerja di sekolah menengah kejuruan. Jurnal Kependidikan, 2(1), 116-127.

Sani, R. A. (2014). Pembelajaran saintefik untuk implementasi kurikulum 2013. Jakarta: Bumi Aksara.

Sani, R. A. (2016). Penilaian autentik. Jakarta: Bumi Aksara.

Saputra, R. D. (2016a). Penerapan metode pembelajaran PjBL (PBL) untuk meningkatkan prestasi belajar kompetensi Computerised Aided Design (CAD) dengan software inventor siswa kelas XI Teknik Pemesinan di SMK Negeri 2 Klaten (Skripsi tidak diterbitkan). Universitas Negeri Yogyakarta, Yogyakarta.

Saputra, Y. E. (2016b). Penerapan metode pembelajaran project-based learning (PjBL) untuk meningkatkan keaktifan dan hasil belajar perekayasaan sistem kontrol siswa kelas XII EI 3 SMK N 3
Wonogiri (Skripsi tidak diterbitkan). Universitas Negeri Yogyakarta, Yogyakarta.

Schuetz, R. (2018). Project-based learning: Benefits, examples, and resources. Diunduh dari https://www.schoology. com/blog/project-based-learning-pblbenefits-examples-and-resources.

Syahri, B., Syahril, \& Yuliana. (2015, Oktober). Strategi pembelajaran problem solving di SMKN 10 Padang. Makalah dipersentasikan pada $3^{\text {rd }}$ International Conference on Technical and Vocation Education and Training (TVET). Fakultas Teknik Universitas Negeri Padang, Bukittinggi.

Syamsuriyanti, \& Sukirno. (2018). Faktor determinan profesionalisme guru. Jurnal Kependidikan, 2(1), 56-67.

Wena, M. (2014). Strategi pembelajaran inovatif kontemporer: Satuan tinjauan konseptual operasional. Jakarta: Bumi Aksara. 